\title{
PERGADUHAN KAUM DI TANAH MELAYU SELEPAS PENDUDUKAN JEPUN HINGGA DARURAT DIISYTIHARKAN
}

\author{
Mohamed Ali bin Haniffa \\ Mohammad Redzuan bin Othman
}

\begin{abstract}
This article examines the ethnic conflict that occurred in Malaya after the end of the Japanese Occupation till the declaration of the Emergency in 1948. The Japanese Occupation worsened the already strained relations between the Malays and the Chinese. This dissatisfaction was reflected by the number of racial clashes that occurred after the Japanese army surrendered. One of the nuain factors for the source of the conflict after the end of the war, it appears, was the challenge to the position of Islam in the comtry. The Malay conmunify lost their trust in the Chinese after the Three-Star army interfered with religious ceremonies in mosques and suraus. The Malay comminity which was synonymous with Islam, used religion as a vehicle to protect the interests of the community. As a result of tortures and killings by the Three-Star amny, a religiousbased novenent, emerged among the Malays to preseroe the sanctity of the religion and to protect the interests of the Malays. This article showes that Islam inspired the rise of nationalism anong the Malays based on Islam not only to protect the religion but ultimately to free the country.
\end{abstract}

\section{Pendahuluan}

Malaysia merupakan sebuah masyarakat majmuk dengan penduduk berbilang kaum, agama dan budaya. Kemajmukan masyarakat di Tanah Melayu menjadi lebih unik dengan kedatangan kaum imigran 
hasil galakan penjajah British selain kesempitan hidup di negara asal masing-masing. Disebabkan kaum-kaum utama yang tinggal di Tanah Melayu hidup secara berasingan berasaskan geografi dan kegiatan ekonomi, masalah perpaduan antara kaum merupakan isu penting dalam perkembangan sejarah Malaysia. Selain masalah ini, hubungan yang tidak erat antara kaum di Malaysia juga turut diburukkan dengan dasar pecah dan perintah yang diamalkan oleh pemerintah British dan diteruskan semasa pemerintahan Jepun. Selain tidak wujudnya perpaduan, turut wujud prasangka yang tebal dalam kalangan pelbagai etnik ini.

Dasar pecah dan perintah oleh pemerintah British ternyata telah meminggirkan orang Melayu daripada arus pemodenan. Lantaran itu, pendekatan Jepun yang memberi gambaran bahawa mereka memberikan keutamaan kepada orang Melayu dan menindas orang Cina telah memberi impak negatif dalam hubungan antara dua kumpulan etnik ini. Pendudukan Jepun yang singkat ternyata merupakan faktor utama yang membawa kepada pergaduhan apabila tempoh "kosong" selepas penyerahan kalah Jepun digunakan oleh orang Cina untuk melakukan keganasan bagi membalas dendam. Pertumpahan darah yang berlaku meletakkan Tanah Melayu di ambang kehancuran dan memaksa British dan pemimpin tempatan daripada pelbagai kaum berusaha mengembalikan keharmonian antara kaum. Pelbagai usaha bersifat kemasyarakatan dan keselamatan dilakukan bagi mencapai matlamat ini. Pengukuhan semula pentadbiran British ternyata berjaya menyekat suasana tidak terkawal menjadi lebih terurus. Menjelang darurat diisytiharkan pada tahun 1948, kes pergaduhan antara kaum telah berkurangan dan masyarakat dapat hidup dalam suasana harmoni.

\section{Masyarakat Majmuk dan Bibit Perpecahan Kaum}

Masyarakat majmuk di Tanah Melayu telah dibentuk sejak zaman kerajaan Melayu Melaka apabila terdapat pelbagai bangsa dan agama hidup secara aman dan saling bekerjasama. Menurut beberapa pengkaji sejarah seperti O.W. Wolters dan Wang Gungwu, Melaka mula mengamalkan sikap toleransi kepada pelbagai bangsa sejak pemerintahan Sultan Iskandar Syah (Parameswara) dan dua orang pengganti selepasnya.' Mereka menggalakkan para pedagang luar datang ke pelabuhan Melaka sehingga terdapat lapan puluh empat bahasa yang dipertuturkan di pelabuhan Melaka. ${ }^{2}$

Kesultanan Melayu Melaka mempunyai hubungan yang erat di antara Melaka dengan negeri China sehingga mendorong maharaja Dinasti Ming menubuhkan Jabatan Bahasa Melaka (Bahasa Melayu) 
bagi meningkatkan hubungan ekonomi antara kedua-duanya. ${ }^{3}$ Malah Abdullah Munsyi dalam bukunya Hikayat Abdullah turut mencatatkan bahawa penduduk kota Melaka adalah terdiri daripada pelbagai kaum. ${ }^{4}$

Pembentukan masyarakat majmuk di Tanah Melayu menjadi semakin pesat selepas penjajahan British apabila British menggalakkan penghijrahan masuk orang Cina dan orang India tanpa kawalan. Kemasukan mereka adalah bertujuan untuk mengusahakan lombong bijih timah dan juga membuka tanah baru bagi penanaman ladang getah. ${ }^{5}$ Mengikut Anand, penduduk Tanah Melayu berjumlah seramai 250,000 pada tahun 1800 dan bilangan ini meningkat kepada 2,000,000 pada tahun 1900 dan 6.3 juta pada tahun 1957.6 Daripada jumlah ini peningkatan yang paling ketara melibatkan kaum imigran Cina. Menjelang tahun 1921 bilangan orang Cina di Tanah Melayu adalah seramai 1,171,740 juta orang. Bilangan ini terus meningkat kepada $1,704,452$ orang pada tahun 1931 dan 2,614,667 orang pada tahun $1947 .{ }^{8}$ Penglibatan orang Cina dalam kegiatan ekonomi membolehkan mereka mempunyai kedudukan ekonomi yang kukuh berbanding orang Melay u dan India. Ketidakseimbangan yang berlaku ini menyebabkan kaum Melayu merasa kurang senang ${ }^{9}$ sehingga hubungan antara kaum terus renggang dan sukar untuk mewujudkan perpaduan dalam erti kata sebenar.

\section{Faktor Pencetus Pergaduhan Kaum}

Pend udukan Jepun di Tanah Melayu mer upakan faktor utama sehingga berlakunya pergaduhan di antara orang Melayu dan Cina. Ini berpunca daripada dasar Jepun yang gagal mengambil kira kemajmukan Tanah Melay u ketika itu. ${ }^{10}$ Sikap anti China tentera Jepun yang dilatari oleh peperangan di Manchuria turut mewarnai layanan yang mereka berikan kepada orang Cina di Tanah Melayu. Selain itu, dalam usaha untuk mengukuhkan pemerintahannya di Tanah Melayu, pemerintah Jepun juga turut memberikan beberapa kelonggaran kepada orang Melayu bagi memenangi mereka. Pendekatan Jepun ini ditafsirkan oleh orang Cina sebagai satu pengkhianatan sehingga menyebabkan mereka terasa dianiaya.

Usaha awal Jepun memenangi hati orang Melayu dapat dilihat sebaik-baik sahaja mereka berjaya menguasai Tanah Melayu setelah mengalahkan tentera British. Ini termasuklah mengadakan kunjungan dan bertemu dengan pemimpin di peringkat akar umbi. Tujuannya ialah bagi mengucapkan terima kasih dan mencanangkan kembali slogan "Asia untuk orang Asia". "Kemenangan, semangat keperwiraan, keberanian dan kesetiaan kepada pemerintah ini telah ditonjolkan 
kepada penduduk di Tanah Melayu. ${ }^{12}$ Za'ba sendiri pernah menyatakan bahawa "Di Alor Star kami telah menjadi tamu kepada Tuan Yang Terutama Tsukigawa, iaitu seorang yang sangat lemah-lembut dan murah pada segala istiadatnya. Dia seorang yang disukai oleh orang ramai di dalam Kedah. Mereka memandangnya sebagai bapa kepada hamba ra' yat sekalian". ${ }^{13}$ Selain itu pendakwah Islam yang berbangsa Jepun telah dihantar ke kawasan Asia bagi mendapatkan sokongan serta menjalankan kerja-kerja propaganda bahawa penaklukan yang sedang berlangsung ialah suatu perjuangan suci bagi menegakkan cita-cita "Lingkungan Kemakmuran Asia Raya". ${ }^{14}$

Di Tanah Melayu, orang Cina meneruskan sentimen kebencian terhadap bangsa Jepun dengan menjalankan pemulauan terhadap mereka. Pemulauan tersebut membawa kepada pembunuhan seramai 70,000 orang Cina diSingapura kerana Jepun melabelkan kesemua orang Cina berkenaan sebagai komunis. ${ }^{15}$ Terd apat juga gerakan penentangan terhadap Jepun yang dikenali sebagai "Anti-Japanese Army". ${ }^{16}$ Seramai 13 orang penduduk ${ }^{17}$ di Mukim Sega, Raub telah diseksa kerana membantu askar British yang diketuai oleh Tuan D. Headly ketika mereka melalui Mukim Sega dalam bulan Julai $1945 .^{18}$ Orang Melayu telah dipaksa oleh Jepun untuk menjadi tali barut dan hal ini telah disalah tafsir oleh masyarakat Cina.

Dasar campur tangan British terhadap Negeri-negeri Melayu telah memberikan kuasa yang luas kepada British untuk memanipulasi kekayaan di Tanah Melayu. Artikel Enam dalam Perjanjian Pangkor memperuntukkan seorang Pegawai British dilantik sebagai seorang Residen. ${ }^{19}$ British sentiasa menganggap bahawa mereka ialah pemerintah dan mengamalkan polarisasi perkauman. Mereka juga tidak mengiktiraf hak kemanusiaan dan menganggap orang lain sebagai hamba. ${ }^{20}$ Oleh itu, beberapa orang pengkaji seperti Brian Harrison dan Wan Hashim Wan Teh menjelaskan bahawa masalah perpaduan sudahpun wujud sejak zaman kolonial lagi. ${ }^{21}$

Polisi pecah dan perintah menyebabkan keadaan menjadi semakin buruk kerana keadaan ini tidak memungkinkan hubungan baik terjalin antara mereka. ${ }^{22}$ Akhbar Saudara bertarikh 30 November 1932, mengkritik polisi British dengan menyatakan "Kita tidak sekali-kali terfikir bahawa kerajaan yang maha adil ini hanyalah semata-mata memikirkan perbendaharaannya sahaja, tidak menaruh timbangan sama ke atas rakyat negeri yang akan ditimpa oleh marabahaya kesusahan hidup di dalam masa yang dahsyat yang hendak dijalankannya cukaicukai bagi maslahat perbendaharaannya itu". ${ }^{23}$ Orang Eropah di luar dari Tanah Melayu memandang pendudukan Jepun sebagai " $a$ God-sent 
chance to clear up all the country's troubles". ${ }^{24}$ Kejatuhan Tanah Melayu juga menunjukkan dengan jelas kelemahan polisi divide and rule British.

Rasa tidak puas hati terhadap dasar kolonial serta percaturan ekonomi yang tidak seimbang telah disuarakan oleh orang Melayu ketika berlaku zaman kemelesetan ekonomi dunia yang melanda Tanah Melayu antara tahun 1929-32. ${ }^{25}$ Hal ini dilihat oleh orang Melayu sebagai suatu ancaman besar kepada situasi politik dan ekonomi mereka ${ }^{26}$ sedangkan perniagaan orang Cina menjadi semakin makmur dan meningkat. Helmut G. Callis, seorang ahli ekonomi menganggarkan bahawa jumlah keseluruhan pelaburan orang Cina di Tanah Melayu pada tahun 1937 ialah sebanyak USD 200 juta (lebih kurang $£ 40,000,000) .{ }^{27}$ Manakala jumlah pelaburan dari pemodal lain ialah sebanyak $\$ 454.5$ juta (lebih kurang $£ 90,900,000$ ). ${ }^{28}$ Kegawatan ekonomi telah menyebabkan British turut campur tangan dalam bentuk repatriasi buruh yang sudah kehilangan pekerjaan, kewujudan kerja bantuan sebagai pekerjaan sementara dan pemberian tanah kepada golongan imigran. ${ }^{29}$

Penguasaan ekonomi yang tidak seimbang telah membawa kepada berlakunya percanggahan dalam budaya kehidupan. Usaha telah diadakan supaya orang Melayu yang mudah memberi dan menerima tidak dicabar. ${ }^{30}$ Kenelm O.L. Burridge menyatakan:

Before the war we and the Chinese lived in peace. But now they want to swallow the people (makan orang). We Muslims do not chase money. That is the Chinese way. They are not Muslims and they do not have the same understanding (faham). If they became Muslims it would be all right. ${ }^{31}$

Gambaran "kasar dan tidak beradab" telah menimbulkan batasan pergaulan di antara orang Melayu-Cina. ${ }^{32}$ Bilangan imigran lelaki yang melebihi wanita telah membawa kepada masalah pelacuran. Pada tahun 1901 terdapat 100 orang wanita berbanding dengan 1000 orang lelaki imigran Cina di Negeri-negeri Melayu Bersekutu (NNMB). ${ }^{3.3}$ Apabila kelebihan ekonomi melebihi sesuatu kaum, maka akan berlaku pelanggaran ke atas norma kehidupan. Misalnya di bandar Penggaram, Johor, terdapat kelompok komuniti Cina yang suka duduk membuang masa di kedai makan dalam keadaan tidak menghormati adat dan budaya masyarakat setempat. ${ }^{34}$ Di samping itu mereka juga dikatakan telah membawa budaya berjudi dan minum arak yang agak bertentangan dengan norma kehidupan masyarakat Melayu Islam. ${ }^{35}$

Selain itu, orang Cina menguruskan sekolah, rumah ibadat serta kemudahan yang lain tanpa mengira pandangan masyarakat setentpat. 
Pergaduhan orang Melayu dan Cina juga berlaku disebabkan oleh provokasi oleh sesuatu pihak kepada pihak yang lain. Akibat dari rasa takut serta sifat perkauman yang sangat kuat, orang Cina sering kali menaruh prasangka terhadap segala aktiviti orang Melayu, sehinggakan apabila orang Islam berkumpul di surau atau masjid dengan bertahli1 "La illa ha il Allah" mereka menyangka orang Melayu menyeru "Lai ll" (marilah). ${ }^{36}$ Mereka juga mengatakan bahawa orang Melayu menyeru hantu atau semangat orang Melayu yang mati dibunuh olehnya datang membalas dendam. ${ }^{37}$

Rasa benci serta dendam ke atas etnik yang lain menyebabkan pelbagai cerita dan spekulasi dibuat bagi menimbulkan ketegangan. Antaranya ialah kejadian luar biasa yang berlaku pada waktu malam sehingga orang Cina hidup dalam ketakutan. Perkara sebegini telah berlaku di Setapak dan Ulu Gombak pada 18 Januari 1946. ${ }^{38}$ Dalam banyak laporan akhbar menyatakan bahawa pemimpin orang Cina tidak cuba untuk menasihatkan komuniti mereka agar hidup dalam keadaan yang harmoni dan tidak mencetuskan pergaduhan. ${ }^{39}$

\section{Kesedaran Masyarakat Melayu-Islam}

Faktor utama yang telah mencetuskan konflik berdarah antara orang Melayu dan Cina ialah apabila berlaku pencabulan ke atas kesucian ag ama Islam. ${ }^{40}$ Masyarakat Melayu telah hilang kepercayaan terhadap komuniti Cina apabila tentera Bintang Tiga mula mengganggu upacara keagamaan di surau dan masjid. ${ }^{41}$ Peristiwa tersebut telah berlaku pada bulan puasa di Batu Pahat, Johor sebelum tentera Jepun menyerah kalah. Tentera Bintang Tiga telah melarang orang Melay u berkumpul di surau atau masjid untuk mengerjakan sembahyang terawih dan beribadat ser ta berjemaah. ${ }^{+2}$ Larangan serta sekatan berkenaan telah menjadikan orang Melayu semakin bersatu. Perkara yang sama juga telah berlaku di Perak dan Batu Pahat semasa orang Melayu mengerjakan sembahy ang Jumaat. Gerila Cina menggunakan kesempatan membunuh orang Me layu dengan menembak dan membakar masjid ketika mereka sedang ber sembahyang. ${ }^{43}$ Selain itu masjid telah dicemari dengan kejadian seperti menyembelih dan memasak khinzir ${ }^{44}$ dan orang Melayu telah dipaksa untuk menyertai gerila Cina. ${ }^{45}$ Misalnya kawasan masjid Air Hicam, Muar telah digunakan bagi menyembelih khinzir sehingga me nyebabkan masyarakat setempat terganggu ketika menjalankan iba dat. ${ }^{46}$

Isu perkauman menjadi dominan selepas pemerintahan Jepun dan diburukkan lagi dengan tindakan British yang seolah-olah cuba un:uk mempermainkan kesucian agama Islam. Pada 18 Julai 1947, 
Mejar Cock telah menggunakan al-Quran dalam majlis angkat sumpah kepada semua belia Islam yang menyertai tentera British. ${ }^{47}$ Dalam majlis angkat sumpah berkenaan, rekrut yang beragama Islam telah diarahkan memegang Al-Quran di tangan kiri dan mengangkat tangan kanan untuk melafazkan ikrar. ${ }^{48}$ Tindakan Mejar Cock telah menimbulkan perasaan marah dalam kalangan sultan dan juga orang Islam di Tanah Melayu. ${ }^{49}$ Bantahan telah disuarakan dalam akhbar Utusan Melayu dan surat bantahan telah dihantar kepada British. ${ }^{50}$ Keadaan ini diburukkan lagi apabila Gabenor tidak memaklumkan perkara tersebut kepada Majlis Islam Tertinggi. ${ }^{51}$

Penindasan serta perencanaan penjajah yang tidak seimbang telah menyebabkan masyarakat Melayu mula memikirkan survival bangsa mereka. Dalam konteks perjuangan politik di Tanah Melayu, fahaman nasionalisme menetapkan bahawa agamalah yang menjadi sumber dan matlamat akhir kepada pembentukan sebuah negara bangsa Melayu hingga disamakan bahawa menjadi Melayu dan negara bangsa Melayu itu mestilah beragama Islam. Agama telah menjadi tenaga pendorong dan penguat kepada kesedaran dan perjuangan orang Melayu. Pengaruh Islam dalam konteks perjuangan kemerdekaan di Tanah Melayu adalah menonjol lebih-lebih lagi kerana perjuangan awal nasionalisme Melayu dipelopori oleh tokoh dan pemimpin agama atau mereka yang berjiwa agama. Tahun 1945-46 merupakan tahun yang paling genting dan cemas dalam sejarah orang Melayu. Pada ketika orang Melayu sedang diancam oleh Bintang Tiga, kerajaan British telah mengkhianati orang Melayu dengan mengisytiharkan di Parlimen British, London hasratnya untuk menjadikan negeri-negeri Melayu sebagai tanah jajahannya yang dikenali sebagai Malayan Union. ${ }^{52}$

Dalam mempertahankan survival bangsa, golongan ulama di kebanyakan negeri di Tanah Melayu seperti Terengganu, Kelantan, Kedah, Pahang, Perlis, Perak dan Pulau Pinang telah memainkan peranan penting sebagai role model. ${ }^{53}$ Antara tokoh ulama yang terkenal ialah Syeikh Haji Fadhil Al-Banteni ${ }^{54}$ yang merupakan guru kepada ramai ulama di Tanah Melayu. ${ }^{55}$ Kedatangan ulama ke negeri-negeri Melayu dilihat telah dapat menyuntik semangat jihad dalam kalangan penduduk setempat ${ }^{56}$ sepertimana pernah berlaku dalam gerakan membantu pergerakan Islam di Champa semasa pemerintahan Sultan Mohamad I (1800-1837) yg dirangsang oleh semangat ukhuwah Islamiyah. ${ }^{57}$ Oleh yang demikian gerakan menentang penjajah pada abad ke-19 telah menggunakan pendekatan agama sebagai paksi utama dalam perjuangan. ${ }^{58}$ 
Tarekat menjadi sebahagian daripada amalan dalam masyarakat Melayu. Menurut Syed Naguib Al-Attas, dua tarekat yang terkenal dan diamalkan dalam kalangan masyarakat Melayu ialah Qadiriyyah dan Naqshbandiyyah.$^{59} \mathrm{Ilmu}$ y ang dibawa dan diajar oleh guru tarekat ialah ilmu batin dan bukannya ilmu zahir. Antara guru tarekat ialah Shaykh Abdullah bin Mustafa di Kampung Parit Maimun, Mukim Simpang Kiri, Batu Pahat, Johor. ${ }^{60} \mathrm{IImu}$ tarekat juga tersebar luas dengan berlakunya penghijrahan ulama dari satu tempat ke tempat yang lain. Pada abad ke-19 ramai ulama dari Patani telah berhijrah ke Terengganu kesan daripada serangan Siam ke atas Patani. ${ }^{61}$ Menjelang awal tahun 1930an, madrasah di sepanjang Sungai Perak digunakan oleh kongsi gelap Melayu serta pertubuhan sulit bagi mengadakan mesyuarat. ${ }^{62}$

Dalam usaha mempertahankan kelangsungan survival bangsa, elemen mempertahankan diri dalam masyarakat Melayu mula diberikan perhatian. Ilmu silat merupakan suatu seni mempertahankan diri yang disertai dengan beberapa amalan ilmu kebal ataupun batin. Oleh yang demikian keyakinan dan amalan agama amat mirip kepada paduan unsur-unsur setempat dengan mistik sufi yang terdapat di seluruh Alam Melayu.$^{63}$ Amalan ilmu kebal dalam kalangan masyarakat Melayu telah muncul sebelum Perang Dunia Kedua. British yang memang sudah mengetahui fenomena ini mengambil sikap berdiam diri dengan harapan tidak akan menjadi kronik. Orang Melayu pula mempunyai tanggapan bahawa amalan tersebut serta penglibatan dalam pertubuhan sulit dan kongsi gelap ialah Perang Jihad. ${ }^{64}$

Elemen ini telah menimbulkan kebimbangan kepada pentadbiran British dan isu ini terus berlanjutan sehingga $1946 . .^{65}$ British mengakui sendiri bahawa ilmu kebal yang diamalkan oleh orang Melayu khususnya di Johor dan Perak telah mengganggu pentadbiran mereka. ${ }^{66}$ Mereka juga cuba untuk mengkaji elemen Sabilillah dan ilmu kebal serta menganggap bahawa kedua-d uanya adalah berbeza. "Terdapat laporan yang menyatakan bahawa Sabilitlah adalah kumpulan yang menentang orang Cina. ${ }^{68}$ Walau bagaimanapun kenyataan ini telah disalah tafsirkan oleh para orientalis barat. Hakikatnya, Gerakan Sabilillah merujuk kepada perjuangan untuk mempertahankan agama dan masa hadapan orang Melayu daripada diganggu gugat oleh penjajah.

Ilmu kebal juga mendapat pengaruh dari Indonesia dan mula dilaporkan pada November 1945 di Negeri Sembilan. Sejak tempoh tersebut, ilmu tersebut telah diperluaskan hingga ke seluruh Semenanjung Tanah Melayu dan Singapura. ${ }^{69}$ Antara objek yang digunakan bagi menjadikan seseorang pengamal itu kebal jalah kain selendang merah, cincin, ${ }^{70}$ potongan ayat dari Al-Quran, ${ }^{71}$ dan suntikan 
jarum emas. ${ }^{72}$ Terdapat juga penggunaan ilmu halimunan yang telah dibawa oleh Tuan Guru Haji Abbas ${ }^{73}$ di Sungai Choh, Hulu Selangor. ${ }^{74}$ Kiai Salleh bin Karim dikatakan kerap kali datang ke Ulu Cheka, Jerantut, Pahang bagi membincangkan survival orang Melayu bersama Pawang Nong bin Santan. ${ }^{75}$ Beliau juga adalah pengikut serta pengamal Tarekat Qadiriyyah yang diasaskan oleh Sheikh Abdul Qadir Jilani dan mempraktikkan seni silat sendeng. ${ }^{76}$

Ilmu kebal yang disertai dengan amalan minum air penebat bertujuan untuk merangsang serta menaikkan semangat perjuangan menentang Bintang Tiga. Pada September 1946, Syeikh (Syed) ldris yang berketurunan Jawa mula mengajar ilmu kebal serta mistik Melayu di daerah Kuala Kangsar, Perak. Menjelang bulan Julai 1947, konflik di antara Melayu dan Cina bertambah serius di sepanjang Sungai Perak. Orang Melayu telah menjadikan parang panjang sebagai senjata utama bagi mempertahankan nyawa mereka. ${ }^{77}$ British memandang pengamalan ilmu kebal orang Melayu sebagai suatu bentuk ancaman baru kepada mereka dan menegaskan bahawa ilmu kebal ini akan membawa kepada amuk. ${ }^{78}$

\section{Meletus dan Merebaknya Pergaduhan Melayu dan Cina}

Menurut Cheah Boon Kheng, Gerakan Sabilillah ialah anti-Cina dan antiMPAJA. Gerakan ini bermatlamat mempertahankan kesucian agama Islam dan orang Melayu akibat daripada pembunuhan kejam serta penyeksaan y ang dilakukan ke atas mereka. ${ }^{79}$ Pergaduhan Melayu-Cina di Johor telah bermula antara Mac hingga Ogos $1945 .{ }^{80}$ Pergaduhan di Johor bermula di Ayer Hitam pada 20 Jun 1945 (bermula antara petempatan dari Muar ke Parit Sulong). Kejadian kedua telah berlaku pada 21 Jun 1945 di Parit Kuman, Mukim Sungei Balang. ${ }^{81}$ Pada bulan Mei 1945 telah berlaku pembunuhan ke atas Moain Saridin@Shahidin ${ }^{82}$ dan Hassan Akasah, ${ }^{83}$ manakala pergaduhan terakhir telah berlaku di Mukim Sri Menanti pada 22 Ogos $1945 .{ }^{84}$ Pada 20 Ogos 1945 seramai dua orang Cina telah dibunuh oleh orang Banjar di Batu 14, Sri-Menanti, Jalan Parit Jawa Muar. ${ }^{85}$ Pada 2 September 1945, Dato' Sheikh Abdullah bin Yahya ${ }^{86}$ telah diculik oleh orang Cina dan dicederakan oleh mereka. Beliau akhirny a telah meninggal dunia akibat kecederaan parah pada 5 September $1945 .{ }^{87}$ Selain itu, Ja' afar bin Abu Bakar ${ }^{88}$ dan Daeman bin Arshad telah dibunuh oleh tentera Bintang Tiga pada 24 September 1945 di Sanglang, ${ }^{89}$ manakala Sikam bin Gempal telah dibunuh oleh gerila Bintang Tiga di Parit Lintang, Pontian. ${ }^{90}$ 
Hubungan Melayu dan Cina di Segamat mulai renggang dan terdapat beberapa kejadian pertumpahan darah berlaku di sana. ${ }^{91}$ Provokasi ini merupakan sebahagian dari tindakan yang telah dilakukan oleh komunis dalam merenggangkan hubungan antara orang Melayu dan Cina. Kekacauan juga telah berlaku pada malam 9 Februari 1946 bersamaan hari Sabtu dan pada tengah hari Ahad 10 Februari 1946 di Bukit Gambir dan Parit Samsu, Johor. ${ }^{92}$ Selain itu, pergaduhan kecilkecilan juga sering kali berlaku di beberapa lokasi yang didiami oleh orang Melayu dan Cina seperti yang berlaku di Pengerang. ${ }^{93}$

Pada 10 Jun 1945, MPAJA telah membunuh seorang Pegawai Daerah Batu Pahat, Ismail Abdullah, Tuan Haji Hasbullah (Kadi Batu Pahat), dan Dr. Woodhull (Pegawai Perubatan Batu Pahat) ${ }^{94}$ ketika berunding dengan MPAIA di Benut, Johor. ${ }^{95}$ Berikutan dari keganasan orang Cina ke atas orang Melayu, tentera Sabil Selendang Merah (Holy War Army of the Red Bands) telah dibentuk oleh Kiai Salleh di Simpang Kiri, Batu Pahat, Johor. Beliau telah menggabungkan penduduk Melayu yang terdiri daripada dua suku yang berlainan iaitu Jawa dan Banjar. ${ }^{96}$ Senjata yang digunakan berupa parang panjang, lembing, keris, pedang dan tombak manakala MPAJA menggunakan senjata api. Kiai Salleh telah membahagikan struktur tentera Sabil Selendang Merah kepada beberapa bahagian. Di bahagian Selatan Johor dibahagikan kepada tiga orang pemimpin iaitu Kiai Kusin, Kiai Mashudi dan Kiai Mayor (Moh). Di bahagian Timur Johor pula diketuai oleh Kiai Saudi, Kiai Maskam dan Kiai Sarbini. Manakala di Utara Johor diketuai oleh Kiai Mustahir, Kiai Haji Shamsuddin dan Kiai Haji Shukor. ${ }^{97}$ Kiai Salleh bin Abdul Karim sendiri telah dibantu oleh Kiai Wak Joyo. Konflik etnik yang telah bermula di Simpang Kiri, Batu Pahat telah merebak hampir ke seluruh mukim di Batu Pahat. Dalam satu kejadian yang berasingan sebanyak 60 buah keluarga Cina di Kampung Batu Pahat telah lari meninggalkan harta benda apabila sekumpulan orang Melayu dan Jawa mencari mereka dengan bersenjatakan parang. ${ }^{98}$ Beberapa kejadian juga telah dilaporkan di Benut dan Rengit. Perjuangan Kiai Salleh mempertahankan survival bangsa tidak terhenti setakat di Simpang Kiri sahaja malah hampir di seluruh daerah Batu Pahat. ${ }^{99}$

Pergaduhan Melayu-Cina di Johor telah merebak hingga ke Sungai Manik, Perak. Pergaduhan di Sungai Manik ${ }^{101}$ telah berlaku antara 15 Ogos 1945 hingga 15 September $1945 .{ }^{101}$ Isu sensitif di mana satu kaum diserang oleh kaum yang lain sengaja disebarkan dengan harapan akan berlaku pergaduhan sesama mereka. ${ }^{102}$ Bintang Tiga juga telah mula menjalankan propaganda untuk merekrut ahli-ahli baru. ${ }^{103}$ Menurut Tuan Haji Zakaria bin Awang, ketua bagi orang Cina 
yang dikenali sebagai Gwo Bin dan Ah Loy ${ }^{104}$ telah bermesyuarat di Parit 7. ${ }^{105}$ Dalam situasi cemas itu penduduk kampung mencari ulama yang boleh mengajar mereka ilmu kebal atau ilmu tidak lut senjata. ${ }^{106}$ Antara ulama yang menjadi tumpuan di Sungai Manik ketika itu ialah Tuan Haji Amirus Hussin, Tuan Haji Yusof, Tuan Haji Marzuki, ${ }^{107}$ Tuan Haji Dahlan, Tuan Haji Mat Samad, Tuan Haji Anuar ${ }^{108}$ dan Tuan Haji Masmuda. Tuan Haji Bakri bin Haji Mohd Saman telah bertindak sebagai Tuan Guru atau pakar rujuk, ${ }^{109}$ manakala Tuan Haji Bakri telah dilantik menjadi khalifah parang panjang. Beliau dibantu oleh Tuan Haji Shukor yang bertindak sebagai Naib Khalifah. ${ }^{110}$ Berita mengenai amalan ilmu kebal Sungai Manik telah sampai ke merata tempat. Penduduk dari Kampung Tebuk Banjar ${ }^{111}$ seramai dua belas orang telah pergi ke rumah Imam Haji Bakri bin Haji Mohd Saman dengan tujuan untuk menuntut ilmu kebal. ${ }^{112}$

Pengumuman Jepun menyerah kalah pada 15 Ogos 1945 iaitu pada bulan Ramadhan telah menyebabkan MPAJA dan MPAJU semakin berani mengisytiharkan kuasa mereka. ${ }^{113}$ Bintang Tiga telah mula menghukum penduduk kampung khususnya orang Melayu. Misalnya, terdapat antara mereka yang diikat kaki serta tangannya dan dimasukkan ke dalam guni lalu dicampakkan ke dalam laut hiduphidup. ${ }^{114}$ Kemuncak kemarahan orang Melayu apabila sebuah masjid di Parit $6 \mathrm{C}$ mahu dijadikan sebagai bilik gerakan dan dewan drama oleh Bintang Tiga. ${ }^{15}$ Kejadian seumpama ini menyebabkan Tuan Haji Ugoh bin Haji Mohd Said bersama penduduk kampung mula mempersiapkan diri bagi mempertahankan kampung halaman mereka. ${ }^{116}$ Tuan Haji Ugoh bin Haji Mohd Said dan beberapa orang pemuda berjumpa dengan Imam Haji Bakri bin Haji Mohd Saman di Parit 8 B, Sungai Manik bagi membincangkan kedudukan masyarakat kampung. ${ }^{17}$ Sehubungan itu, Tuan Guru Imam Haji Bakri telah mengisytiharkan perang jihad melawan orang kafir yang telah cuba mempersendakan agama serta nyawa orang Melayu. Kumpulan ini telah diberikan minum air jampi yang dikenali sebagai air penebat dan telah dianugerahkan Selendang Merah. ${ }^{118}$ Kumpulan pemuda yang diketuai oleh Tuan Haji Ugoh bin Haji Mohd Said telah diberikan pesanan oleh Tuan Guru Imam Haji Bakri bin Haji Mohd Saman seperti berikut:

Perjuangan ini adalah syahid. Qada dan Qadar telah ditetapkan oleh Allah S.W.T.. Kalau ditakdirkan mati dibunuh, maka akan matilah dibunuh. Sentiasa amalkan kalimah La hi la la hillallah dan ayat empat. 119 
Orang Melayu ketika itu hanya bersenjatakan parang panjang, keris dan pisau. Komuniti Banjar Melayu menggunakan istilah "mencantas" bagi merujuk kepada konflik berdarah ini. ${ }^{120}$ Pergaduhan Melayu-Cina yang mula merebak menyebabkan orang Cina yang tinggal di Kampung Koh, Sitiawan, Ipoh, Kampar, Langkap dan Chucap datang memberikan bantuan kepada orang Cina yang masih menetap di Sungai Manik. ${ }^{121}$ Boleh dikatakan hampir setiap hari akan berlaku peristiwa pergaduhan kecil yang melibatkan orang Melayu dengan Bintang Tiga. Pergaduhan ini disertai dengan beberapa perkara ganjil yang berlaku dengan izin Allah S.W.T. ${ }^{122}$ Pergaduhan Melayu-Cina di Sungai Manik yang dikenali juga sebagai kebangkitan orang Banjar akhirnya telah mula merebak ke merata tempat di negeri Perak. ${ }^{123}$

Pergaduhan Melayu-Cina di Perak terus merebak sehinggakan kampung-kampung tradisional Melayu menjadi mangsa kekejaman orang Cina. Bintang Tiga telah menjadikan Sekolah Melayu Bekor sebagai markas Bintang Tiga. ${ }^{24}$ Mereka memaksa penduduk Kampung Bekor mendengar ceramah serta propaganda komunis di Sekolah Melayu Bekor. Seramai sebelas orang penduduk Kampung Bekor telah dipanggil untuk disoal siasat oleh pihak Jepun. Ini diikuti pula oleh kumpulan penduduk kampung yang lain. ${ }^{125}$ Gerakan menyoal penduduk kampung telah diteruskan pada 11 Januari 1944. ${ }^{126}$ Akhbar Majlis telah melaporkan seperti berikut:

... seluruh Kampung Bekor yang dulunya sangat-sangat menyokong
keras akan gerakan kerajaan Bintang Tiga telah ditukarkan tuhan
akan perasaan dan rohnya lalu mereka itu berpaling tadah dan
mula menentang segala pujukan-pujukan yang mengandungi
racun daripada bangsa Cina yang mengajak lagi supaya orang
Melayu bercampur dengannya untuk menghalau British daripada
Semenanjung Tanah Melayu dan kemudiannya Tanah Melayu ini
diperintah oeh tiga bangsa... 127

Penglibatan beberapa orang ulama tempatan seperti Tuan Haji Salleh bin Abdul Manan, Tuan Haji Abdul Rahman bin Abdul Manan dan Tuan Haji Shahbudin bin Lebai Sulaiman Bakul telah berjaya membawa perubahan baru di Kampung Bekor. Terdapat juga penglibatan beberapa orang Syeikh dari Bagan Serai seperti Tuan Syeikh Osman. ${ }^{28}$ Penyatuan penduduk Melayu Bekor seperti yang telah dilakukan oleh para ulama tempatan telah menyebabkan hubungan dan kepercayaan mereka terhadap masyarakat Cina berubah. Dalam satu peristiwa seramai 100 orang Cina telah bertempiaran lari apabila dikejar oleh orang Melayu. Mereka telah merosakkan tanaman orang 
Melayu ketika kerja membina jalan selebar enam kaki. ${ }^{129}$ Keadaan yang mencemaskan di Bekor akibat tekanan orang Cina telah menyebabkan wakil orang Melayu mengemukakan tiga tuntutan kepada orang Cina. Akhbar Seruan Ra'ayat melaporkan seperti berikut:

Sa-orang guru Tauhid di-Manong di-dalam suatu mashuarat antara China dengan Melayu kerana hendak mendamaikan perkelahian di-situ telah mengeluarkan 3 tuntutan dengan chakap yang keras dan menghentam-hentam meja dengan tinju-nya sa-hingga ChinaChina yang di-dalam mashuarat itu puchat muka-nya ${ }^{130}$

Tuntutan pertama adalah memulangkan semula orang Melayu yang telah ditangkap atau yang dibawa ke dalam hutan. Sekiranya mereka ini telah dibunuh, orang Melayu telah memohon ditunjukkan kubur agar mereka boleh dikebumikan semula mengikut cara Islam. Mereka juga telah menuntut kembali harta benda milik orang Melayu yang telah dirampas serta dirompak oleh Bintang Tiga. Tuntutan ketiga ialah menyerahkan semua senjata seperti senapang yang berada dalam simpanan mereka kepada pihak kerajaan. ${ }^{131}$

Serangan Bintang Tiga ke atas Kampung Bekor telah berlaku selama dua hari. Serangan pertama yang disifatkan lebih kepada tindakan Bintang Tiga untuk menguji kekuatan dan persediaan orang Melayu berlaku pada 5 Mac 1946 hari Selasa jam 10.00 pagi, ${ }^{132}$ telah berjaya dipatahkan oleh penduduk kampung. ${ }^{133}$ Pada hari Rabu 6 Mac 1946, lebih kurang jam $5.00^{134}$ hingga ke 5.30 pagi $^{135}$ telah berlaku serangan kali kedua yang dirancang dengan penuh teliti ketika kebanyakan penduduk kampung masih sedang tidur. ${ }^{136}$ Dalam serangan tersebut, setiap kawasan simpang dan jalan utama di seluruh kampung telah dikawal ketat oleh Bintang Tiga. Antara tokoh yang menjadi teraju utama bagi mempertahankan penduduk Melayu Bekor ialah Tuan Haji Abdul Rahman bin Abdul Manan, Tuan Haji Salleh bin Abdul Manan, Tuan Haji Kulub Alang dan beberapa orang tokoh tempatan. ${ }^{137}$ Keadaan yang terkepung telah menyebabkan ramai kanak-kanak serta kaum wanita yang sedang tidur menjadi mangsa. ${ }^{138}$ Akhbar Majlis melaporkan bahawa bilangan orang Cina yang datang menyerang ialah kira-kira 500 orang dan serangan yang datang dalam dua kumpulan ini dibuat dari daerah Klian. ${ }^{139}$ Laporan BMA menyatakan "It is not known where the attackers came from and as they dispersed rapidly in thick jungle country". ${ }^{40}$ Taktik serangan adalah dengan membunyikan beduk di masjid sehingga menyebabkan penduduk kampung berada dalam keadaan kelam-kabut khususnya dalam memberikan bantuan. ${ }^{141}$ 
Peristiwa 6 Mac 1946 telah meninggalkan kesan yang mendalam khususnya kepada penduduk Melayu di Kampung Bekor. Dalam serangan yang dianggarkan selama dua jam ini, seramai 80 orang Melayu termasuk kanak-kanak telah dibunuh. Bilangan penduduk yang paling ramai menemui ajal ialah penduduk yang sedang bersolat subuh di Masjid Kampung Bekor. ${ }^{142}$ British dalam satu laporan menyatakan seramai 70 orang Melayu telah dibunuh di Masjid Bekor (Bikaw). ${ }^{143}$ Laporan British menyatakan bahawa pihak Cina tidak mengalami sebarang kehilangan nyawa dan serangan ini telah dirancang dengan begitu rapi. ${ }^{144}$ Pada 7 Mac 1946 bersamaan hari Khamis, penduduk Kampung Semat telah bersepakat pergi ke kampung-kampung yang terlibat bagi mencari mangsa korban untuk tujuan pengebumian. Walaupun bilangan anggota Bintang Tiga yang dibunuh oleh orang Melayu dikatakan ramai, namun mayat mereka tidak ditemui oleh penduduk kampung. ${ }^{45}$ Persoalan ini masih menjadi tanda tanya sehingga ke hari ini.

Kekacauan serta pembunuhan ke atas orang Melayu terus berlangsung hampir di semua lokasi di Tanah Melayu. Pada 19 September 1945, berlaku pembunuhan ke atas orang Melayu di Kota Bharu (Kelantan), 26 September 1945 di Alor Gajah (Melaka), di Selangor, ${ }^{146}$ Selama, Taiping, Parit, ${ }^{147}$ Sitiawan (Perak) dan Terengganu. Dalam kejadian di Sitiawan, seramaj tujuh orang Cina terbunuh, dua cedera dan beberapa buah rumah dibakar. Pada hari berikutnya komunis membunuh serta mencederakan beberapa orang penduduk kampung. ${ }^{148}$ Pada 6 November 1945, dalam satu serangan balas, sekumpulan 300 hingga 400 orang Melayu telah menyerang orang Cina di Padang Lebar, Kuala Pilah ${ }^{149}$ dan seramai 40 orang Cina terkorban. ${ }^{150}$ Kebanyakannya terdiri daripada wanita dan kanak-kanak. ${ }^{151}$ Dalam kejadian di Batu Malim, Raub, Pahang pada 11 Februari 1946, kekacauan berlaku di kawasan pasar yang melibatkan seramai 200 orang Melayu dan 150 orang Cina. Seramai 30 orang Cina telah terkorban termasuk 10 orang kanak-kanak Cina dan dua orang Melayu. Manakala 16 orang Cina dan 10 orang Melayu yang lain telah mengalami kecederaan. ${ }^{152}$

\section{Kesimpulan}

Orang Melayu telah menjadi mangsa kekejaman, akibat Bintang Tiga yang mahu mengambil tampuk pemerintahan selepas Jepun menyerah kalah. Orang Melayu pula menganggap komunis itu Cina dan Cina itu komunis. Pergaduhan Melayu-Cina selepas pemerintahan Jepun berlanjutan sehingga ke tahun 1950-an. Menurut Khoo Kay Kim, fenomena kebangkitan dan kemarahan orang Melayu memberi kejutan 
kepada pihak British yang selama ini menyifatkan orang Melayu mudah menurut perintah. Kedatangan bangsa asing yang tidak menghormati kedaulatan Melayu telah sedikit sebanyak mencabar ketuanan Melayu. Kekejaman MPAJA melakukan pembunuhan ke atas orang Melayu telah menyebabkan mereka menggabungkan seni mempertahankan diri dan ilmu kebal bagi mempertahankan survival bangsa. Islam digunakan sebagai paksi perjuangan mereka dan penentangan terhadap keganasan MPAJA dianggap jihad ke jalan Allah.

Sikap lepas tangan British, pengenalan Malayan Union dan pengisytharan darurat sedikit sebanyak telah menambahkan tekad orang Melayu lebih-lebih lagi apabila ia melibatkan pelanggaran ke atas kesucian agama Islam. Orang Melayu yang terdesak telah membentuk jamaah dan bersatu di bawah panji-panji Islam. Survival melalui parang panjang bukanlah bersifat perkauman, biarpun akibat dari penentangan terhadap komunis Cina akhirnya membenihkan perasaan perkauman yang sukar dipadamkan. Pergaduhan Melayu-Cina selepas pemerintahan Jepun merupakan jihad pertama orang Melayu. Orang Melayu diakui sebagai bangsa yang penuh dengan kesantunan serta tenang tetapi pantang dicabar apabila berlaku pencabulan ke atas budaya kehidupan serta pelanggaran ke atas kesucian agama Islam. Biarpun pada mata kasar kelihatan orang Melayu seperti mengamuk dan membunuh orang Cina, namun hakikatnya mereka membunuh komunis, yang bukan sahaja terdiri daripada orang Cina, malah penyokong-penyokong komunis daripada orang Melayu juga turut menerima padahnya.

\section{Nota}

1 Menurut Tome Pires, selepas kemangkatan Parameswara, penduduk Melaka dianggarkan kira-kira 6,000 orang. Winstedt dalam bukunya History of Malaya menyebut penduduk Melaka meningkat kepada 40,000 orang dewasa ketika pemerintahan Sultan Alauddin, dan menjadi 190,000 orang sebelum Portugis menyerang Melaka. Lihat Berita Harian, 1 Jun 2010.

2 Zainal Abidin b. Abdul Wahid, Kerajaan Melaka Dalam Hubungan Antarabangsa, dalam Polemik Sejarah Malaysia (Jilid 1), Kuala Lumpur: Arkib Negara Malaysia, 2008, hlm. 124.

3 Raja Ming telah mengarahkan penubuhan jabatan bahasa asing untuk memudahkan hubungan di antara tetamu asing atau para perwakilan berinteraksi dengan negeri China. Mereka melatih kakitangan kerajaan untuk menguasai bahasa Melaka supaya dapat menjalankan kerja-kerja istana melalui terjemahan, dengan tidak menimbulkan kekeliruan. Jabatan Bahasa Melaka merupakan salah satu jabatan di antara 8 jabatan bahasa asing. Lihat Obaidellah b. Haji Mohamad, Kesultanan Melaka: Dari Bahan 
Sejarah China Melihat Aspek Ekonomi, dalam Polemik Sejarah Malaysia (Jitid 1), Kuala lumpur: Arkib Negara Malaysia, 2008, hlm. 312

Abdullah Munsyi mencatatkan hubungan antara kaum di Melaka begitu kuat dan harmonis sehingga seorang budak yang nakal dari satu bangsa boleh ditegur oleh bangsa lain. lbu bapa budak yang dipukul atau ditegur itu akan berterima kasih kepada mereka kerana mengambil berat perlakuan atau perangai anaknya. Lihat Zahari A. Rashid, KenangKenangan Abdullah Munsyi, Petaling Jaya Selangor: IBS Buku Sdn. Bhd., 2008, hIm. 15.

5 Just Faaland, Jack Parkinson, Rais B. Saniman, DEB Pertumbuhan dan Ketaksamarataan, Kuala Lumpur: Dewan Bahasa dan Pustaka, 1991, hlm. 5 .

- S. Anand menulis dalam buku beliau yang bertajuk Inequality and Poocrty in Malaysia-Measurement and Decomposition, London: Oxford University Press, 1983, hlm. 2.

7. Seramai 379,028 orang dari suku Hokkien, 331,757 Kantonis, 217,697 Hakka (Kheh), 130,026 Tiechiu (Teochiu), 68,200 Hainanese (Hailam), 998 Kwongsai, 13,821 Hokchiu, 4,058 Hokchia, 1659 Henghwa (Hinhoa) dan 24,496 dari lain-lain suku. Lihat M.V. Del Tufo, A Report On The 1947 Census of Population, Singapore: The Government Publications Bureau Singapore, 1949 , hlm. 75 .

8 M.V. Del Tufo, A Report On The 1947 Census of Population, him. 75.

- Kritikan terhadap eksploitasi ekonomi oleh orang Cina dapat diperhatikan dalam penulisan novel lshak Haji Mohammad (Pak Sako) yang bertajuk Anak Mat Lela Gila dan Putera Gunung Tahan. Lihat Sivachandralingam Sundara Raja, 'Pembangunan Ekonomi Dan Hubungan Kaum Di Tanah Melayu, 1500-1957,' Seminar Kebangsaan Ketamadunan, Hubungan Etnik \& Kokurikulum 2007, 20 \& 21 Mac 2007, Muzium Seni Asia, Universiti Malaya, hlm. 9.

10. Abu Talib Ahmad, 'Darurat Dan Perpaduan Antara Kaum,' Persidangan Kebangsaan Mengenai Dato' Onn Jaafar, 1 4 Disember 2006, Anjuran Badan Perhubungan UMNO Negeri Johor dan Yayasan Warisan Johor, hlm. 3 .

11 Menurut keterangan Yesuke Matsuoko, Ketua Utusan Nippon sewaktu Perdebatan Marshokoku dalam Mesyuarat Lembaga Bangsa di Geneve pada tahun 1932, cita-cita untuk membentuk penyusunan baru di Asia telah lahir sejak zaman pemerintahan Meiji, walaupun bentuknya belum jelas lagi. Lihat Fajar Asia, Sichigatsu 2603, No. 10, Tahun 1, hlm. 316.

12 Bangsa Jepun lebih rela mati di medan peperangan. Menurut mereka, ianya adalah lebih baik daripada kematian seseorang di atas perbaringan tempat tidurnya. Lihat Fajar Asia, 15 Gogatsu 2603, No. 7, Tahun 1, hIm. 223.

13 Fijar Asia, No. 13, Jugatsu 2603, Tahun 1, hlm. 406.

14 Antara pendakwah Islam berbangsa Jepun ialah Sheikh Haji Muhammad lbrahim Kayabuki yang berkesempatan datang ke Singapura. Lihat Fajor Asia, No. 5, 13 Shigatsu 2603, Tahun 1, hlm. 136.

$15 \mathrm{CO} 537 / 3757$ (27-28), Political Developments Chinese Affairs. 
16 WO 203/5642 (1), The Anti-Japanese Union.

17 Tiga belas orang yang telah ditangkap dan diseksa oleh pihak Jepun ialah Abas bin Sham, Ibrahim bin Yat, Abd. bin Daud, Abd. Kadir bin Ibrahim, Abd. Majid bin Ibrahim, Satar bin Mat Dahan, Yusuf bin Abu Bakar, Omar Baki bin Abdullah dan Abd. Latif bin Andak. Kesemua mereka telah ditangkap pada 7 Ogos 1945 dan dibebaskan pada 30 Ogos 1945. Seramai empat orang telah ditangkap pada 9 Ogos 1945 dan dilepaskan pada 14 Ogos 1945. Mereka ialah Syed Abdul Rahman, Mat Zin bin Tawi, Mat Salleh bin Mat Yatim dan Yaakob bin Gendot. Lihat Pej. Istana S.P. 229/1947 (1-2), Penghulu Sega, Raub, Mukim of Sega kepada Yang Mulia Tengku Nasruddin A.D.C. to H.H. Pahang, 17 September 1947.

18 Ini menangkis pandangan bangsa lain yang menyatakan bahawa orang Melayu merupakan komuniti yang tidak terjejas akibat dari pendudukan Jepun. Lihat Pej. Istana S.P. 229/1947 (1-2), Asst. Penghulu Sega, Raub, Mukim of Sega kepada Yang Mulia Tengku Nasruddin A.D.C. to H.H. Pahang, 17 September 1947.

19 PatrickSullivan, Social Relations Of Dependence In A Malay State: Nineteenth Century Perak, Kuala Lumpur: Art Printing Works, 1982, hlm. 15.

20 MU 1099/1946 (298[2]), Daily Press Summary-28.12.46, Min Sheng Pau (Chinese Daily) Dated 28.12.46.

21 Brian Harrison dan Wan Hashim Wan Teh menegaskan bahawa dasar kolonial yang menyebabkan masalah dalam hubungan kaum, ketegangan serta konflik kaum. Slogan White Man Burden dan polisi Dioide and Rule telah berjaya memisahkan etnik di Tanah Melayu sebagaimana aspirasi British. Lihat Wan Hashim, Race Relations in Malaysia, Kuala Lumpur: Heinemann Educational Books (Asia) Ltd, 1983, hlm. 16.

22 Ho Hui Ling, 'Darurat Dan Perpaduan Antara Kaum, Persidangan Kebangsaan Mengenai Dato' Onn Jaafar, 1-4 Disember 2006, Anjuran Badan Perhubungan UMNO Negeri Johor dan Yayasan Warisan Johor, hlm. 2.

23. Siti Rodziyah Nyan, Akhbar Saudara Pencetus Kesedaran Masyarakat Melayu, Kuala Lumpur: Dewan Bahasa dan Pustaka, 2009, hlm. 107-108.

24 A.J.Stockwell, British Policy And Malay Politics During The Malayan Union Experiment, Malaysian Branch of The Royal Asiatic Society, Monograph No.8., Kuala Lumpur: Art Printing Works, 1979, hlm. 17.

25. Kebimbangan orang Melayu terhadap golongan imigran telahpun disuarakan oleh para intelegensia Melayu seperti Za'ba dan Ishak Haji Muhammad sejak tahun 1930-an lagi. Lihat Abu Talib Ahmad, 'Darurat Dan Perpaduan Antara Kaum,' hlm. 3.

26 Cheah Boon Kheng, Red Star Over Malaya: Resistance and Social Conflict During and After The Japanese Occupation of Malaya, 1941-1946, Singapore: Singapore University Press, 1983, hlm. 5.

27 Victor Purcell, The Chinese in Malaya, London: Oxford University Press, 1948, hIm. 235.

23 Ibid

29. Lesen Pendudukan sementara (TOL) telah dikeluarkan bagi mengambil hati orang Cina. T.S. Adam, Residen Selangor (1932-1937) 
telah mengeluarkan arahan, agar tanah TOL hanya boleh digunakan untuk menanam tanaman jangka pendek seperti sayur-sayuran di Selangor. Lihat Siti Rodziyah Nyan, Akhbar Saudara Pencetus Kesedaran Masyarakat Melaylu, hlm. 101-102.

30 Just Faaland, Jack Parkinson, Rais B. Saniman, DEB Pertumbuhan dan Ketaksamaratian, hlm. 6.

31 Kenelm O.L. Burridge, 'Racial Relations in Johore,' Australian Journal of Politics and History, Vol. II, No. 2, May 1951, hlm. 163.

32 Ibid

33 Victor Purcell, The Chinese in Malaya, hlm. 174.

34 Kenelm O.L. Burridge, 'Racial Relations in Johore,' hlm. 166.

35 Ibid.

36 Seruan Ra'ayat, 21 November 1945.

37. Keadaan ini telah menyebabkan orang-orang Cina tidak boleh tinggal dalam suasana aman dan sentiasa risau pada waktu malam. Lihat Seruan Ra'ayat, 17 November 1945.

38 Sentimen ini juga menyebabkan beberapa orang peniaga Cina bersama keluarga mereka di Setapak dan Ulu Gombak berpindah ke tempat lain bagi menyelamatkan diri. Rasa takut serta propaganda yang melampau menyebabkan British mengeluarkan arahan, agar semua senjata yang dimiliki oleh orang Melayu diserahkan kepada pihak berkuasa British. Lihat Seruan Ra'ayal, 19 Januari 1946.

39 MU 1099/1946 (291[1]), Kuala Lumpur Daily Press Summary-Vernacular papers-No. 68, Majlis (Malay Daily) Dated 20.12.46.

40 Berdasarkan kepada kajian lapangan yang telah dijalankan di Batu Pahat, Johor, Sungai Manik di Perak, Bekor di Kuala Kangsar, Perak, Padang Lebar di Batu Kikir, Negeri Sembilan dan Batu Malim di Raub, Pahang sentimen Islam telah menjadi faktor segera kepada meletusnya pergaduhan Melayu-Cina selepas pemerintahan Jepun. Lihat Hairi Abdullah 'Kebangkitan Dan Gerakan Tentera Selendang Merah Dalam Sejarah Daerah Muar Dan Batu Pahat,' Jebat, Bil. 3/4, 1973/4, 1974/5, hIm. 9.

$41 \quad$ Ibid., hlm. 9.

42 Ibid., hlm. 8 .

4.3 Kenelm O.L. Burridge, 'Racial Relations in Johore,' hlm. 163.

44 Jbid.

45 Ibid.

46 Hairi Abdullah, 'Kebangkitan Dan Gerakan,' hlm. 9.

47 MU. Sec. 8434/47 (1), Telegram Dari Secretary Mijlis Islam Tertinggi Malaya kepada Governor, Malayan Union, Kuala Lumpur, 18.7.47.

4. MU. Sec. 8434/47 (2), Extract From Straits Times ("Koran, British Minta Ma'af"), 19.7.47.

49 MU. Sec. 8434/47 (5), Secretary To Resident Commissioner Perak kepada The Deputy Chief Secretary, The Secretariat, Kuala Lumpur, 10 Aug. 47.

5) MU. Sec. 8434/47 (1), Telegram Dari Secretary Mijlis Islam Tertinggi.

51 MU.Sec. 8434/47 (2), Deputy ChiefSecretary kepada Secretary To Resident Commissioner, Perak, 25 July 1947. 
52 Nik Anuar Nik Mahmud, 'Dato Onn Jaafar Dan Strategi Pengukuhan Ketuanan Melayu,' Persidangan Kebangsaan Mengenai Dato Onn Jaafar, 1-4 Disember 2006, Anjuran Badan Perhubungan UMNO Negeri Johor dan Yayasan Warisan Johor, hIm. 1.

5. Ramai antara ulama yang lahir pada abad yang ke-18 tetapi peranan aktif mereka jelas kelihatan menjelang abad ke-19. Antaranya ialah Haji Ishak bin Muhammad Hashim, tokoh ulama Kedah yang lahir pada tahun 1771 dan meninggal dunia pada tahun 1871. Lihat Samsu Adabi Mamat, 'Kedudukan dan Peranan Ulama Melayu Abad Ke-19', dalam Farid Mat Zain (editor), Islam di Tanah Melayu Abad Ke-19, Shah Alam: Karisma Publications Sdn. Bhd., 2007, hIn. 96.

$54 \quad$ Kiayi Haji Fadhil al-Banteni atau lebih dikenali sebagai Kiayi Fadhil Lenga ialah seorang tokoh ulama dan ahli tarekat yang terkenal di Muar sekitar tahun 1910 hingga 1950. Beliau berasal dan dilahirkan di Banten, Jawa Barat pada tahun 1287 Hijrah bersamaan dengan tahun 1870 Masihi. Keluarga beliau lebih ramai tinggal di kawasan Liuliang, sebuah petempatan kecil berhampiran Bogor. Bapa beliau, Haji Abu Bakar bin Abu Kassim merupakan seorang ulama terkenal di Banten. Bapa beliau pernah dilantik menjadi wakil kesultanan di Banten mengislamkan masyarakat Jawa di sekitar Pulau Jawa. Lihat Mohd Akbal Abdullah, 'Kiayi Fadhil Al-Banteni', dalam Abu Bakar A. Hamid, Md. Ismail Zamzam, Kamdi Kamil (editor), Johor Mengenang Sumbangsilmmi, Johor Bahru: Yayasan Warisan Johor, 2006, hlm. 31.

55 Antara yang telah berguru dengan Syeikh Haji Fadhil Al-Banteni pada peringkat awal terdiri dari Kadi Haji Ahmad Syah dari Pontian, Kiai Salleh bin A bd. Karim (Batu Pahat), di Muar oleh Orang Kaya Haji Abdul Hamid dan di Mersing oleh Haji Siraj bin Marzuki. Perjuangan Kiayi Fadhil alBanteni telah diteruskan oleh anak beliau iaitu Haji Abdul Hamid bin Haji Fadhil. Lihat Mohd Akbal Abdullah, 'Kiayi Fadhil Al-Banteni', hlm. 31.

56 Tuan Haji Ishak dikatakan telah berhijrah ke Pahang sejak tahun 1880an. Pulau Tawar pada ketika itu merupakan sebuah kubu kuat dan perkampungan pahlawan Pahang yang terkenal iaitu Imam Perang Rasul atau Tok Gajah. Pahang yang ketika itu berada di zaman awal penjajahan British telah berjaya diserapkan dengan elemen Islam. Lihat Farid Mat Zain \& Amnah Saayah Ismail, 'Peranan Ulama Terhadap Perkembangan Islam di Pahang Pada Abad Ke-19', dalam Farid Mat Zain (ed.), Islam di Tanah Melayu, hlm. 195-197.

57 Mohamad Abu Bakar, 'Tanah Melayu Abad Ke-19, Pengislaman Penjajahan dan Pemupukan Manhaj Melayu', dalam Farid Mat Zain (ed.), Islam di Tanah Melayu, hlm. 195.

58 Menurut Abdullah Zakaria Ghazali, tahap kekuatan peranan agama tersebut berbeza antara satu gerakan dengan gerakan yang lain sehingga kadang kala menimbulkan kesukaran. Haji Abdul Rahman Limbong dikaitkan dengan idea Perang Sabil dalam kalangan masyarakat petani. Beliau menjelaskan bahawa Perang Sabil bukan sahaja untuk menegakkan agama, tetapi juga untuk menuntut hak yang lain sama ada hak ekonomi, politik atau sosial. Lihat Yahaya Abu Bakar, 'Kebangkitan Tok Janggut 
Menentang Jepun,' Malaysia in History, Vol. 19, No. 1, June 1976, hlm. 25. Islam telah digunakan sebagai teras dalam perjuangan Tok Janggut di Kuala Muda, Kedah.

59 Syed Naguib Al-Attas, Some Aspects of Sufism As Understood And Practiced Among The Malays, Singapore: Malaysian Sociological Research Institute Ltd., 1963, hlm. 34.

60) Shaykh Abdullah bin Mustafa mengamalkan Tarekat Qadiriyyah. Beliau mempunyai tanah seluas lima ekar dan mengusahakan penanaman kelapa dan kopi. Beliau dan isterinya tinggal di sebuah rumah beratap nipah yang telah dihadiahkan oleh penduduk kampung. Sebagai balasan kepada ilmu yang dicurahkan oleh beliau selaku guru tarekat, penduduk kampung bersepakat menyediakan keperluan harian mereka. Kebanyakan penduduk kampung tersebut merupakan imigran dari Jawa. Shaykh Abdullah bin Mustafa juga berasal dari Banten dan telah berhijrah ke Johor ketika berusia 19 tahun. Beliau telah menjadi pakar rujuk dan dukun dalam kalangan penduduk kampung. Lihat Syed Naguib Al-Attas, Some Aspects of Sifism, hlm. 34.

-1 Antara ulama dari Patani yang telah berhijrah ke Terengganu kesan dari serangan Siam ke atas Patani ialah Sheikh Abdul Kadir bin Wan Abdul Rahim. Beliau dikatakan berketurunan Raja Bugis bernama Fakeh Ali yang telah menetap di Patani. Apabila kembali ke Terengganu beliau telah mengikut tradisi pengajian ilmu dengan membuka pondok di Bukit Bayas, Kuala Terengganu sehingga beliau dikenali sebagai Tok Sheikh. Kadir Bukit Bayas. Di Terengganu sebuah pondok yang termasyhur dan berpengaruh telah diasaskan oleh Sayyid Abdul Rahman al-Idrus (1817-1911) dan dikenali dengan nama Tok Ku Paloh. Terdapat pondok pengajian lain di Terengganu yang bergerak pada abad ke-19 seperti Pondok Tok Kali di Sungai Rengas, Pondok Haji Abdul Hamid di Kampung Tebauk, Kuala Terengganu, Pondok Haji Hussin di Kampung Lapu, Besut, Pondok Haji Hassan di Kampung Gong Surau, Besut, Pondok Haji Said di Kampung Lama, Besut dan Pondok Haji Mat Shafie, Losong, Kuala Terengganu. Lihat Faudzinaim Haji Badaruddin, 'Pendidikan Pondok dan Peranannya di Tanah Melayu Abad Ke-19 Masihi' dalam Farid Mat Zain (editor), Islam di Tanah Melayii, hlm. 123-124.

6.2 Antara kongsi gelap Melayu yang berpengaruh ialah Bendera Putih dan Bendera Merah. Idea jihad serta pembaharuan yang diuar-uarkan telah menjadikan madrasah menjadi tumpuan bagi mendengar idea serta seruan jihad terhadap orang bukan Islam. Pengaruh kongsi gelap Perak River Secret Society menjadi dominan pada tahun 1933 dan kuasa Sultan serta polis digunakan bagi mengekang aktivitinya. Lihat A.J. Stockwell, British Policy, hlm. 151.

b3 William R. Roff, Nasionalisme Melayu, Kuala Lumpur: Penerbit Universiti Malaya, 1967, hlm. 6.

ot A.J. Stockwell, British Policy, hlm. 151. 
6.5 CO 537/1583 (5), J.J. Paskin, Colonial Office, Downing Street, S.W.I. (SECRET) kepada Sir Edward Gent, 22October, 1946.

no CO 537/1583 (8), Sir Edward Gent kepada Paskin, King's House, Kuala Lumpur, Malayan Union (SECRET), $8^{\text {th }}$ October, 1946.

6. Barat membuat tafsiran bahawa Sabilillah telah bermula ketika zaman Nabi Muhammad s.a.w. apabila perang jihad diisytiharkan bagi mempertahankan agama. Muslim yang gugur syahid akan ditempatkan di syurga. Idea ini telah diperluaskan kepada istilah "amuk" apabila berlaku pelanggaran ke atas kesucian agama Islam dan juga tempat beribadat. Lihat CO 537/1583 (9), Defence Security Officer (Malayan Union), kepada H.E., The Governor, Malay an Union, King's House (SECRET), $7^{\text {th }}$ October $1946,1946$.

68 CO537/1583 (10), Defence Security Officer (Malayan Union), kepada H.E., The Governor, Malayan Union, King's House (SECRET), $7^{\text {th }}$ October 1946, 1946.

69 Ibid.

7) Penggunaan cincin kebal dapat dikesan di Bekor, Kuala Kangsar, Perak. Lihat Wawancara dengan Tuan Haji Abdul Aziz bin Shaari di Kampung Kubang Udang, Bekor, Kuala Kangsar, Perak, 20 November 2008.

7 Potongan ayat dari Al-Quran seperti Tasbih Nabi Yumus menjadi ayat wajib yang diamalkan oleh semua pengamal ilmu kebal. Kesimpulan ini dibuat hasil dari wawancara dengan beberapa orang pengamal ilmu kebal. Lihat Wawancara dengan Tuan Haji Yahya bin Haji Abbas di Kampung Sungai Choh, Hulu Selangor, 18 Februari 2010.

72 Penggunaan jarum emas dikesan di lokasi berlakunya pergaduhan Melayu-Cina. Lihat A.J. Stockwell, British Policy, hlm. 146-161.

73 Tuan Guru Haji Abbas merupakan guru silat yang disegani di kawasan Sungai Choh. Beliau berasal dari Bangkahulu, Indonesia dan mempunyai banyak kelebihan khususnya yang melibatkan ilmu kebatinan. Wawancara dengan Tuan Haji Yahya bin Haji Abbas.

74 lbid. Sungai Choh ketika itu telah menjadi pusat mempelajari amalan kebal dan juga persilatan.

75. Wawancara dengan Arif bin Nong di Kampung Jenerih, Ulu Cheka, Jerantut, Pahang, 27 November 2007. Syed Naquib al-Attas yang berpeluang melihat parang panjang Kiai Salleh menyatakan bahawa parang panjang tersebut telah memakan mangsa korban seramai 172 orang. Kenyataan ini turut diakui oleh salah seorang sahabat Kiai Salleh bin Karim iaitu Tuan Haji Ali bin Haji Yusuf di Simpang Kiri, Batu Pahat Johor. Tuan Haji Ali bin Haji Yusuf ialah rakan Panglima Salleh yang sama-sama berjuang menentang keganasan Bintang Tiga di daerah Batu Pahat, Johor. Lihat juga Wawancara dengan Tuan Haji Ali bin Haji Yusuf di Kampung Parit Maimun, Batu Pahat, Johor, 19 Mac 2009.

76 Wawancara dengan Tuan Haji Yusof bin Salleh di Johor Bahru, 8 Disember 2009. Lihat juga Zainal Abidin bin Abdullah,'Sepintas Lalu Tentang Seni Persilatan Melayu di Negeri Johor, Jabatan Pengajian Melayu-Sejarah, Maktab Perguruan Lembah Pantai, Kuala Lumpur, 1988, hlm. 4. 
77 British yang gagal mengawal keadaan, menganggap amalan ilmu kebal orang Melayu mengganggu kestabilan masyarakat. Ini adalah kerana kebergantungan orang Melayu kepada sultan dan juga mufti beralih kepada golongan ulama serta pengamal ilmu kebal. Keadaan ini juga berpunca akibat dari ketidakmampuan mereka menghadapi keadaan ini secara berseorangan. Oleh yang demikian mereka kebanyakannya bergantung kepada golongan imam, ulama serta individu lain y ang boleh mempertahankan kewujudan mereka. Lihat CO 537/1583 (12), Defence Security Officer (Malayan Union) kepada H.E., The Governor, Malayan Union (SECRET), Sabilillah and "Invulnerebility", $7^{\text {th }}$ Ok tober 1946.

"C C 537/1583 (12), Defence Security Officer (Malayan Union) kepada H.E., The Governor, Malayan Union, $7^{\text {th }}$ October 1946.

79 Cheah Boon Kheng, 'Sino-Malay Conflict in Malaya, 1945-1946: Communist Vendetta and Islamic Resistance,' Joumal of Southeast Asian History, Vol. 12, No. 1, 1981, hlm. 109.

80 Ibid.

8) SUKJ. 6203/1945 (13 A), Chinese Relief Committee kepada The Officer $\mathrm{i} / \mathrm{n}$ Chinese Affairs, BMA Singapore, 12 November 1945.

82 Moain Saridin $@$ Shahidin merupakan bapa kepada Profesor Dr. Haji Amat Juhari Moain, mantan Dekan Fakulti Komunikasi dan Bahasa Moden, Universiti Putra Malaysia (UPM). Manakala Hassan Akasah ialah bapa saudara beliau. Lihat Uiusan Malaysia, 28 Mei 2009.

83 Semasa ditemui, mayat kedua-duanya tinggal rangka dan tulang, bercampur antara satu sama lain tanpa kepala. Kejadian ini berlaku apabila penduduk kampung, penghulu, orang alim dan pendekar dibunuh kerana enggan memberikan sokongan dan kerjasama kepada komunis. Dalam satu kejadian lain di Kampung Sungai Tongkang, Batu Pahat, sekumpulan komunis menyerang rumah penghulu. Mereka ditembak bertubi-tubi sebelum dibakar, menyebabkan kira-kira 30 orang yang berlindung di rumah berkenaan mati. Kejadian ketiga telah berlaku pada 1 Julai 1945 di Semerah iaitu sebuah pekan kecil di daerah Batu Pahat. Pergaduhan berkenaan telah merebak dari kawasan Semerah ke Sungei Balang. Lihat Litusan Malaysia, 28 Mei 2009.

84 SUKJ. 6203/1945 (13 A), Chinese Relief Committee, Muar kepada The Officer i/n Chinese Affairs, BMA Singapore, 12 November 1945.

s5 RCJ. 241/46 (123), Soh Chiow Y'ew, Sungei Pulai, Mukim of Sri-Menanti kepada Resident Commissioner, Johore Bahru, 8 April 1947.

86. Dato' Sheikh Abdullah bin Yahya ialah bekas Pegawai Daerah Mersing. Lihat SUKJ. 6203/1945 (47), Major G.W.D. Johnson, 1.A.O.C, Civil Affairs Officer, BMA (M), Muar kepada SCAO Region 6, H.Q. BMA (M) Johore Bahru, 12 Februari 1946.

8. RCJ. 241/46 (167), Sheikh Mohamed Taufek, C/O Food Control Dept. Johore Bahru kepada The Hon'ble The Resident Commissioner, Johore, 8 Julai 1947.

8* RCJ. 241/46 (A), Abu Bakar bin Ja'afar, Penghulu Kayu Ara Pasong, Pontian, kepada District Officer, Pontian, 18 Mei 1947. 
89 RCJ. 241/46 (81 A), Abu Bakar bin Ja'afar, Kayu Ara Pasong, Pontian kepada District Officer, Pontian, 9 Julai 1947.

90 RCJ. 241/46, Hj. Rashid bin Hj. Nasir, C/O Penghulu Kayu Ara Pasong, Pontian, kepada District Officer, Pontian, 20 September 1947.

91 SUKJ. 6112/1945 (90), Political Report for Week 23-29.1.46, 30.1.46.

92 Civil Adviser Officer telah mengadakan mesyuarat bersama dengan semua komuniti di Bukit Gambir bagi menyelesaikan masalah dan aduan komuniti Cina yang mengatakan "takutkan orang Melayu" (fear of the Malay). Mesyuarat bersama dengan wakil orang Cina di Muar telah diadakan pada 11 Februari 1946 dan telah dihadiri oleh CAO, ACAO dan CPO. BMA telah mentafsirkan bahawa sebarang perkelahian kecil diklasifikasikan sebagai konflik etnik. Mogok serta demonstrasi orang Cina di Muar semakin menjadi-jadi dan didalangi oleh elemen keganasan seperti komunis dan Bintang Tiga. Lihat SUKJ. 6203/1945 (47), Major G.W.D. Johnson, I.A.O.C, Civil Affairs Officer, BMA (M), Muar kepada SCAO Region 6, H.Q. BMA (M) Johore Bahru, 12 Februari 1946.

93 RCJ. 65/46 (54), Telegram Dari Resident Commissioner Johore kepada Chief Secretary Malayan Union Kuala Lumpur.

94 Zaharah Nawawi, Panglima Salleh Selentpang Merah, Kuala Lumpur: Dewan Bahasa dan Pustaka, 1995, hlm. 234-235.

95 Ho Hui Ling, 'Darurat Dan Perpaduan Antara Kaum,' hlm. 3.

\% Cheah Boon Kheng, Red Star Over Malaya, hlm. 208.

97 Hairi Abdullah, 'Kebangkitan dan Gerakan,' hlm. 10.

98 CO 537/1580 (3), From Alfsea kepada The War Office, 4 Sep. 46.

99 Berita Minggu, 2 Disember 2007.

100 Seruan Ra'ayat, Ahad, 11 November 1945.

101 Cheah Boon Kheng, Red Star Over Malaya, hln. 230.

102 Ghazali bin Basri, Hilir Perak: Sejarah Hubungan Ras Zaman Pemerintahan Jepun Sehingga Pemerintahan Tentera British (B.M.A) 1942-1946, Latihan Ilmiah, B.A., Jabatan Sejarah, Universiti Malaya, 1974/75, hlm. 31.

10: MPAJA/ Bintang Tiga menggunakan taktik pujuk rayu bagi merekrut ahli-ahli baru. Jika sekiranya pujuk rayu tidak berhasil, maka paksaan berupa ugutan, ancaman bunuh dan penculikan sering digunakan. Penduduk kampung yang tinggal di kawasan yang agak terpencil sering kali menjadi mangsa kekejaman. Mereka akan diserbu pada waktu malam dan ditangkap serta dibawa ke dalam hutan belukar. Pada kebiasaannya mereka akan menerima salah satu daripada keadaan sama ada menjadi anggota Bintang Tiga ataupun menjalani hukuman mati. Tuan Haji Ugoh bin Haji Mohd Said, menggambarkan keadaan kesusahan hidup dengan kenyataan, “...bila siang Jepun cari, bila malam pula Cina Bintang Tiga cari." Lihat Wawancara dengan Tuan Haji Ugoh bin Haji Mohd Said di Parit 3 B, Sungai Manik, Perak, 6 Jun 2008.

104 Gwo Bin $@$ Sing Gwo Bin dan Ah Loy mungkin merupakan nama samaran. Tujuannya adalah untuk melindungi identiti sebenar ahli Bintang Tiga. Wawancara dengan Tuan Haji Ugoh bin Haji Mohd Said.

105 Wawancara dengan Tuan Haji Zakaria bin Awang, Bekas Sidang di Parit 8 C, Sungai Manik, Perak, 5 Jun 2008. Bintang Tiga telah berpakat 
membawa anak-anak gadis penduduk kampung untuk direkrut menjadi kader komunis.

106 Ghazali bin Basri, Hilir Perak, hlm. 35.

10: Tuan Haji Marzuki berketurunan Jawa.

10 Wawancara dengan Tuan Haji Hanapiah bin Haji Salleh di Parit 13 A, Sungai Manik, Perak, 6 Jun 2008.

109 Wawancara dengan Tuan Haji Zakaria bin Awang.

110 Ghazali bin Basri, Hilir Perak, hlm. 35-36.

11] Kampung Tebuk Banjar terletak lebih kurang sepuluh batu dari mukim Sungai Manik ke arah Hutan Melintang Perak.

112 Rombongan seramai dua belas orang terdiri dari Tuan Haji Yusuf, Tuan Haji Johari, T uan Haji Shaari, Tuan Haji Jaafar (Jafak), Satar bin Rashidi, Awang bin Haji Othman, Hassan bin Haji Othman, Haji Nasri, Maamur bin Haji Masjuni, Haji Jaafar bin Haji Saman, Haji Bakri bin Shamsudin dan Tuan Haji Hassan bin Haji San usi. Oleh kerana tempoh mempelajari ilmu kebal ini sangat lama kerana mereka perlu menjalani beberapa amalan seperti solat, puasa dan zikir maka mereka membawa segala keperluan asas yang diperlukan seperti pakaian dan senjata. Penduduk yang datang dari Kampung Tebuk Banjar mempunyai pertalian kekeluargaan yang rapat dengan penduduk di Sungai Manik. Ramai antara saudara mara mereka yang telah membuka tanah sawah di Sungai Manik pada peringkat awal. Justeru itu keperluan seperti penginapan dan makanan tidak menjadi masalah kepada mereka. Lihat Ghazali bin Basri, 'Hilir Perak, ${ }^{\prime}$ hlm. 36.

113 Cheah Boon Kheng, Red Star Ooer Malaya, hlm. 231.

114 Ibrahim Mahmood, Sejarah Periuangan Bangsa Melayu, Kuala Lumpur: Pustaka Antara, 1981, hlm. 32.

115 Ghazali bin Basri, Hilir Perak, hlm. 43.

11. Berserta dengan ilmu kebatinan yang telah dipelajari, menjadikan diri mereka amat yakin untuk berhadapan dengan musuh Islam iaitu Bintang Tiga. Tuan Haji Ugoh bin Haji Mohd Said telah membunuh seorang anggota Bintang Tiga dalam satu pergaduhan kecil yang telah berlaku di Parit 3, Sungai Manik, Perak. Lihat Wawancara dengan Tuan Haji Ugoh bin Haji Mohd Said.

117 Imam Haji Bakri bin Haji Mohd Saman juga dikenali dengan gelaran Pak Haji Bakri dalam kalangan penduduk Sungai Manik. Lihat Wawancara dengan Tuan Haji Abdul Kadir@ Muhammad bin Haji Bakri di Parit 8 B, Sungai Manik, Perak, 5 Jun 2008.

118 Air penebat ialah air yang telah dibacakan dengan ayat-ayat suci AlQuran. Air ini diberikan kepada pejuang sabil apabila mereka hendak menentang musuh. Selendang Merah pula merupakan kain berwarna merah yang ditulis dengan kalimah Allah. Pada kebiasaannya selendang merah ini akan diselempangkan di atas bahu kanan. Terdapat juga selendang yang hanya diikat ataupun dililitkan di kepala sahaja. Menurut Tuan Haji Ugoh bin Haji Mohd Said, selesai sahaja beliau meminum air penebat, jiwanya menjadi tenang dan bertambah berani. Perasaan was-was juga akan hilang dan hanya bertekad untuk mempertahankan 
agama Islam. Mereka juga tidak mempunyai perasaan kasihan kepada orang Cina dan perasaan marah sentiasa membuak. Lihat Wawancara dengan Tuan Haji Ugoh bin Haji Mohd Said.

110 Wawancara dengan Tuan Haji Ugoh bin Haji Mohd Said.

120 Istilah mencantas yang digunakan oleh orang Banjar merujuk kepada memancung ataupun memenggal leher Bintang Tiga.

121 Komuniti Cina dari luar Sungai Manik bukan sahaja datang memberikan bantuan kepada saudara sebangsa mereka yang tinggal di kawasan petempatan orang Melayu tetapi juga membantu perjuangan Bintang Tiga. Lihat Ghazali bin Basri, 'Hilir Perak,' hlm. 43.

122 Perkara-perkara ganjil yang telah berlaku masih menjadi sebutan penduduk Sungai Manik sehingga kini. Antaranya ialah senjata yang digunakan oleh Bintang Tiga ketika menembak orang Melayu tidak meletup. Begitu juga bom tangan yang dilemparkan oleh mereka juga tidak meletup. Bintang Tiga juga melepaskan tembakan ke arah atas kerana mereka memandang musuh mereka tinggi seperti pokok kelapa. Mereka juga dikatakan tidak dapat melihat kelibat orang Melayu dengan jelas. Apa yang disedari oleh mereka ialah apabila parang panjang mengenai leher. Semua perkara ini berlaku dengan izin Allah dan berkat ilmu yang telah diperturunkan oleh Tuan Guru Imam Haji Bakri bin Haji Mohd Saman yang lebih dikenali dengan gelaran Khalifah Parang Panjang. Keadaan yang tidak tenteram menyebabkan pergerakan orang Melayu keluar dari kawasan kampung menjadi terbatas. Orang Melayu yang hendak pergi ke Teluk Intan ketika itu berada dalam keadaan yang amat terancam. Lihat Ghazali bin Basri, 'Hilir Perak,' hlm. 51.

123 WO $172 / 9773$ (234), SECRET, War Diary Of, H.Q. Malaya Command, Weekly Intelligence Review, No. 19, Week Ending 9 March 1946. Lihat juga WO 203/5302 Malaya's Political Climate V, Period December $1^{\text {st }}$ to $20^{\text {th }} 1945$, (TOP SECRET).

124 Wawancara dengan Tuan Haji Abdul Aziz bin Shaari.

125 Antara yang telah dipanggil oleh pihak Jepun ialah Cikgu Haji Ahmad bin Monak, Shaharuddin bin Yeop Abdul Hamid, Alang Ishak, Hamzah bin Ngah Pakar, Mahyuddin, Mat Pora dan Hashim bin Mat Yusuf. Kumpulan ini merupakan kumpulan pertama yang dipanggil oleh Jepun. Mereka telah dibawa dari Balai Polis Manong ke Balai Polis Kuala Kangsar. Seramai tiga orang pend uduk kampung iaitu Harun bin Uda Hassan, Ibrahim Abdullah dan Hashim enggan menyerah diri. Pada 20 Disember 1943 mereka telah lari ke dalam hutan apabila pihak Jepun berusaha menangkap mereka. Proses soal siasat telah dijalankan oleh Sarjan Dahalan yang ketika itu menjadi Ketua Balai Polis Manong. Kesemua mereka telah dituduh membantu gerakan anti-Jepun. Kumpulan ini telah dibawa ke Balai Polis Kuala Kangsar dan telah dipaksa untuk mengaku dan bersumpah. Ada yang diketuk kepala dengan menggunakan kayu cota. Terdapat juga yang direndam ke dalam kolah air. Pegawai yang bertanggungjawab menjalankan penyeksaan ialah Inspektor Ridzuan bin Syeikh Abdul Rahman. Beliau dikenali sebagai Inspektor Che Wan. Ketika pemerintahan Jepun beliau menjawat jawatan Ketua Perisikan Cawangan 
Khas. Pada 5 Januari 1944 kesemua tahanan ini telah dibebaskan dan diberi amaran agar tidak terlibat dalam gerakan menentang Jepun. Lihat Kamaruddin bin Mohd Piah, 'Kampong Bekor sejak 1908, Satu Kajian sejarah tempatan dengan Rujukan Khas kepada Tragedi 6 hb Mac 1946,' Latihan Ilmiah,B.A., Jabatan Sejarah, Universiti Malaya, 1974/1975, hlm. 53.

12b Kumpulan kedua yang dipanggil telah diberi dua pilihan oleh pihak berkuasa Jepun. Mereka telah diarahkan berpindah ke Manong dan Seberang Manong ataupun semua orang lelaki di Bekor menyerah diri di Balai Polis Kuala Kangsar. Kumpulan penduduk Kampung Bekor telah membuat pilihan yang kedua. Seramai 50 hingga 60 orang yang terdiri dari kaum lelaki telah pergi menemui Sarjan Dahalan di Balai Polis Kuala Kangsar. Antara mereka ialah Cikgu Haji Jihin bin Chor dan Cikgu Samin. Lihat Kamaruddin bin Mohd Piah, 'Kampong Bekor Sejak 1900,' hIm. 54. 12. Majlis, 17 Februari 1947.

12s Wawancara dengan Abdul Rahman bin Uda Mohd di Kampung Kubang Udang, Bekor, Kuala Kangsar, Perak, 20 November 2008.

129 Tanaman orang Melayu telah dimusnahkan oleh orang Cina ketika berada dalam zon yang berkenaan. Kerja-kerja ini telah dijalankan tanpa kebenaran dari penduduk kampung. Penduduk Melayu telah berkejar ke tempat kejadian dengan membawa parang panjang dan mengusir pekerja tersebut. Lihat Seruan Ra'ayat, 7 Januari 1946.

130 Seruan Ra'ayat, 7 Januari 1946.

131 Kenyataan ini telah membuktikan bahawa orang Cina telah memulakan pergaduhan terlebih dahulu. Orang Melayu telah mempertahankan hak mereka setelah diganggu-gugat oleh Bintang Tiga. Justeru itu tuduhan yang dilemparkan bahawa orang Melayu yang menjadi punca kepada konflik adalah tidak berasas.

132 Kamaruddin bin Mohd Piah, 'Kampong Bekor Sejak 1900,' h/m. 90.

133. Wawancara dengan Ibrahim bin Uda Mohd di Kampung Suak Petai, Manong, Perak, 21 November 2008.

134 WO 172/9773 (281), SECRET, War Diary Of, H.Q. Malaya Command, 1946, Message Form From Hq Malaya Command To SACSEA, ALFSEA, DTO0 07.

135. Melalui kajian lapangan yang telah dijalankan oleh penulis, kebanyakan saksi menyatakan bahawa peristiwa serangan ini berlaku apabila hari hampir menjelang subuh iaitu di antara jam 5.00 hingga 5.30 pagi.

13. Wawancara dengan Tuan Haji Abdul Aziz bin Shaari. Tuan Haji Shaari bin Haji Amin dan anaknya Abdul Aziz bin Shaari tidak berjemaah di masjid Bekor pada pagi tersebut. Mereka membuat keputusan untuk bersembahyang di rumah pada pagi kejadian. CO 537/1580 (21), Growth Of Inter Racial Feeling In Malaya (SECRET).

13 Senjata yang digunakan oleh orang Melayu bagi mempertahankan diri ialah parang panjang, golok dan keris. Manakala orang Cina menggunakan senapang, serampang, tat dan lembing tat. Antara tokoh yang mempertahankan keselamatan penduduk kampung ialah Tuan Haji Shaari bin Haji Amin dan Daud bin Haji Amin. Tuan Haji Amin bin Kulub 
Hitam, Abdul Munan bin Haji Amin, dan Tuan Haji Abdul Rahman bin Abdul Manan berada di barisan hadapan. Lihat Wawancara dengan Tuan Haji Abdul Aziz bin Shaari.

138 Utusan Melayn, 12 Mac 1946.

139 Majlis, 24 Februari 1947.

$140 \mathrm{CO} 537 / 1580(17-18)$, H. Ralph Hone, Headquarters, British Military Administration, Malaya, Kuala Lumpur kepada Consul-General, Consulate-General of The Republic of China, Singapore, 8 March 1946.

${ }_{141}$ Penduduk kampung tidak mengetahui bahawa beduk bukan sahaja diketuk oleh orang Melayu malah oleh orang Cina. Apabila beduk di Kampung Bekor dibunyikan, maka penduduk Kampung Kelang berkejaran untuk memberikan bantuan. Penduduk kampung Bekor yang terlibat menyatakan bahawa sebanyak 40 buah rumah telah dibakar oleh Bintang Tiga. Lihat Kamaruddin bin Mohd Piah, 'Kampong Bekor Sejak 1900,' hlm. 80 .

142 Wawancara dengan Tuan Haji Abdul Aziz bin Shaari. Nenek beliau telah mati dibunuh ketika sedang bersolat. Jenazah beliau dikebumikan di kawasan masjid (bahagian hadapan masjid).

143 CO 537/1580 (8), Extract From Official Report.

$144 \mathrm{CO} 537 / 1580$ (21), Inward Telegram From Headquarters, B.M.A. (M), To 3, Of S., Colonies, $7^{\text {th }}$ March 1946.

145 CO 537/1580 (17), H. Ralph Hone, Headquarters, British Military Administration, Malaya, Kuala Lumpur kepada Consul-General, Consulate-General of The Republic of China, Singapore.

146 WO 203/5642 (1), Political Climate-Interview By British Authority Admin With Sultans, Aug/Dec. 45.

$14 \mathrm{CO} 537 / 1580$ (20), Inward Telegram From Headquarters, B.M.A. (M), To 3, Of S., Colonies, $7^{\text {th }}$ March 1946.

148 CO 537/5985 (6), Extract From P.M.R. 1 Secret Part l, Political lntelligence Review, Dated $5^{\text {th }}$ January, 1949.

149 Mohd Nor bin Bujal, 'Satu Peristiwa Bersejarah Yang Saya Dapat Saksikan Dari Dekat,' Esei-esei Sejarah Malaysia II, Persatuan Sejarah Malaysia, 1982, hlm. 16. Di Kampung Padang Lebar, Pak Maakin telah dijumpai dibunuh dengan kejam. Perut dan badannya ditikam dengan pisau oleh orang Cina. Mayatnya dikebumikan dalam sebuah lubang yang hanya digali sedalam setengah meter. Semasa dijumpai kaki mayat itu terlunjur keluar.

150 CO 537/1580 (8), Extract From Official Report.

151 CO 537/1580 (11), H. Ralph Hone, Headquarters, British Military Administration, Malaya, Kuala Lumpur kepada Consul-General, Consulate-General of The Republic of China, Singapore.

152 CO $537 / 1580$ (8), Extract From Official Report. Angka awal yang menyatakan seramai 100 orang Cina yang terkorban dalam insiden di Batu Malim adalah tidak benar. Mr. H.Y. Teh dari Raub Chinese Chamber of Comnerce mengesahkan bahawa angka korban yang tepat hanyalah seramai 30 orang Cina sahaja berdasarkan kepada senarai korban yang dimiliki oleh beliau. 